\title{
RELEVANSI PENDIDKAN PANCASILA DAN POTRET MAHASISWA DI PERGURUAN TINGGI
}

\author{
Fransiska Novita Eleanora, Andang Sari \\ FH Universitas Bhayangkara Jakarta Raya, Indonesia \\ Email :siska_ita@yahoo.com
}

\begin{abstract}
ABSTRAK
Penelitian ini bertujuan untuk mengetahui bahwa wujud nyata dari implementasi pendidikan pancasila dan nila-nilai dari setiap sila-sila didalamnya dapat disosialisasikan dengan mengikutsertakan dan melibatkan mahasiswa dalam keikutsertaan tri dharma perguruan tinggi mengembangkan wawasan, pengetahuan bahkan juga keahlian yang sudah didapatkan atau diperoleh selama berada di bangku perkuliahan mempraktekkan keahliannya dalam kehidupan ataupun juga terjuan dan ikut serta dala masyarakat, yang sesuai dengan nila-nilai kehidupan dan juga kemanusiaan juga moral dan norma dalam pancasila. Relevansinya dalam mengimplemantasikan khususnya dalam penelitian juga pengabdian masyarakat, mendapatkan juga memperoleh ilmu di universitas maka mahasiswa dapat juga mengamalkan dan mengabdikan dalam lingkungan tempat tinggalnya, sesuai dengan bidang keahliannya. Metode yang digunakan dalam penelitian ini adalah penelitian pustaka dengan mengkaji buku-buku dan literatur-literatur. Hasilnya adalah Pengamalan Pancasila yang didapatkan atau diterima mahasiswa di perguruan tinggi dapat diterapkan bukan hanya sebatas dilingkungan tempat, tinggalnya saja tetapi juga kepada implementasi Tri Dharma Perguruan Tinggi itu sendiri, dan hal ini akan berdampak luas kepada mahasiswa itu sendiri dalam lingkungan kerjanya nanti yang akan terlihat jika mahasiswa tersebut sudah lulus dan mendapatkan pekerjaannya, sesuai dengan bidang skili dan pengalamannya selama terjun dan mengabdikan dirinya dalam rangka mengimplementasikan Tri Dharma dari Perguruan Tinggi tersebut.
\end{abstract}

Kata Kunci : Mahasiswa; Pendidikan; Perguruan Tinggi

\begin{abstract}
This study aims to find out that manifestation the implementation Pancasila education and the values each the precepts can socialize by involving, and students in tri dharma participation of tertiary institutions develop insights, knowledge and even skills have been obtained or gained during their stay the lecture bench practices its expertise in or enters and participates in society, which is in accordance with the values of life and also humanity as well morals and norms in Pancasila. Relevance in implementation, especially research as well as community service, also getting knowledge of the university, students can also practice and devote to an environment where life, according to their field of expertise. The method used in this study is library research by examining books and literature. The result is practice obtained or accepted by students in tertiary institutions can applied not only to environment, but also the implementation Tri Dharma of Higher Education self, and will have a wide impact on students selves in environment which will later the student has graduated and got his job, in accordance with the field of study and experience during the plunge and devoted self in order to implementation Tri Dharma of the College.
\end{abstract}

Keywords: College Student; Education; Collegee 


\section{PENDAHULUAN}

Bangsa Indonesia sebagai bangsa yang merdeka dan berdaulat memiliki dasar dan falsafah negara yaitu Pancasila, dimana makna pancasila sebagai arti yang penting dalam kehidupan berbangsa dan bernegara, dan mewujudkan masyarakat adil dan makmur yang sesuai dengan kepribadiannya. Pemahaman akan nilainilai dalam pancasila harus diajarkan dan dihayati sejak dini, walaupun berbeda-beda suku, ras yang ada di Negara Indonesia tidak menjadikan perpecahan ataupun permusuhan tetapi justru dengan adanya perbedaan tersebut menjadi pemersatu antar bangsa, dan menjakin keakraban satu sama lainnya. Pengenalan akan makna pancasila yang sejak kecil diberikan kepada generasi dari penerus bangsa yaitu dengan tutur kata dan tingkah laku, artinya mengimplemantasikan kepada masyarakat apa yang sudah diajarkan, karema hal tersebut berkaitan dengan nilai, moral dan norma.

Despan (2014) menyebeutkan nilainilainorma dalampancasilaharus dijelaskan secara kritis dan mendasar karena hal itu juga terkait dengan pembentukan karakter dari suatu bangsa, karakter yang bersifat membangun agar setiap warga masyarakat dapt menghayati dan mengamalkan pancasila dalam kehidupan sehari-hari. Senada dengan itu Anzhar Ishal (2018) bahwa keterkaitan antara pancasila dengan berbagai kegiatan-kegiatan yang dilakukan oleh mahasiswa merupakan bagian dari suatu iyang internalisasi yang kan mengiuatakan wawasan kebangsaan dan ideologi dari pancasila itu sendiri, bahkan harus terus digalakkan agar tidak terjadi kelunturan.

Menurut Natal (2017) bahwa banyak dikalangan bebrbagai mahasiswa tidak paham ajan nilai-nilai pancasila serta hubungannya dengan yang disebut Tri Dharma Perguruan Tinggi, hal ini disebabkan kurangnya peahaman yang tumbuh dalam diri mahasiswa bagaimana mengaktualisasikan sila-sila yang ada Nilai-nilai yang didapatkan dari sejak kecil sampai dewasa dari mulai bangku sekolah sampai perguruan tinggi harus sudah dimanifestasikan dalam kehidupan keluarga, lingkungan dan masyarakat, wujud nyatanya dengan adanya moral yang tumbuh dalam diri setiap orang, perilaku yang baik mencerminkan sikap dan perbiatan yang baik, karena moral dan norma berasal dalam diri sendiri dan memuat akan kesadaran akan tingkah laku yang baik dan yang buruk juga.

Hal ini juga tercermin dengan adanya teori-teori hukum yang ada seperti any farida (2016), teori hukum progressif dimana hukum itu harus berpihak kepada rakyat lebih mengutamakan keadilan, tidak berat sebelah, keadilan yang diperuntukkan oleh masyarakat banyak serta memajukan kehidupan bangsa dan bernegara, dan ada lagi yang disebut dengan teori hukum integratif yaitu bagaimana nilai masyarakat dalam penanganan perkara hukum di Indonesia, masyarakat perlu mengetahui dan memahami landasan hukum dalam penanganan hukum yang ada, aturan yang dianggap sebagai mengikat dan harus diikuti oleh masyarakat, dan lebih diartikan hukum yang hidup ditengah-tengah masyarakat, dan yang terrakhir adalah teori hukum pancasila adalah hukum sebagai suatu produk hukum yanitu peraturan yang mengikat masyarakat baik di daerah maupun di perkotaan.

Kesadaran akan moral dan norma yang ada tanpa harus dipaksa melakukannya, tetapi kesadaran yang ada dalam diri pribadi, demikian juga dengan mahasiswa dapat mengsosialisasikan pemahaman akan nilai-nilai yang sudah mereka dapatkan selama belajar diperguruan tinggi, teori dan pembelajaran mengenai pendidikan pancasila dan kewarganegaaraan, sudah didapatkan, tetapi harus dipraktekkan oleh mahasiswa agar terealisasi dan jelas 
dampak positif yang sudah diterima dan di pahami secara nyata.

Bentuk konkrit sangat jelas tidak hanya diamalkan dan dilaksanakan ditempat tinggal mahasiswa, ataupun di lingkungan kampus, tetapi dalam skoop yang lebih luas lagi dengan yaitu dengan pelaksanaan tri dharma perguruan tinggi, pelaksanaan tersebut tidak hnaya melibatkan dosen sebagai pengajar saja, tetapi mahasiswa juga ikut terlibat didalamnya, Syarbaini (2011) menjelaskan relevansi pendidikan dari sila pertama sampai sila ke lima dapat direalisasikan dalam kegiatan tersebut, adanya keaktifan mahasiswa untuk ikut ambil alih tanpa disuruh dalam aktivitas tersebut.

Mahasiswa sebagai generasi dan penerus dari bangsa mampu dan dapat mengaktualisasikan pancasila, dalam kehidupan bermasyarakat, sebagai ideologi, falsafah dan dasar negara yang harus dihayati dan diamalkan masyarakat dalam kehidupan berbangsa dan bernegara, sehingga perlu sekalai lagi menanamkan kesadaran dan pedoman yang selalu tumbuh dalam pribadi. Berkaitan dengan ketentuan tersebut diatas, penulis tertarik merumuskan masalah bagaimana relevansi pendidikan pancasila dengan potret mahasiswa di perguruan tinggi, terkait dengan pelaksaan tri dharma perguruan tinggi dalam mengembangkan ilmu dan keahliannya

\section{METODE}

Penelitian ini menurut Yusuf (2014) menggunakan jenis penelitian kepustakaan dengan kualitatif yakni dengan mengkaji buku-buku dan literatur-literatur yang ada dan berkaitan dengan masalah yang diteliti, memanfaatkan berbagai teori yang ada untuk mendukung yang ada sehingga dapat menghasilkan teori kembali. Uji suatu keabsahan dalam data suatu penelitian yang disebut kualitatif dilihat dari validitas internal yaitu apaila berkenaan dengan hasil desain dari penelitian yang memang sudah di capai, lalu validitas yang disebut eksternal berkenaan juga dengan adanya hasil dari penelitian yang sudah dapat diterapkan, dan reliabilitas juga sangat berkaitan dengan adanya konsistensi dari suatu stabilitas data dan juga temuan yang ada dan terakhir adalah obyektivitas derajat dari kesepakatn diantara banyaknya orang akan hasil yang sudag dicapai. Sumber data, yang digunakan adalah data sekunder dimana menggunakan refernsi dan jurnal bahkan peraturan perundang-undangan, teknik pengumpulan data dilakukan dengan studi dokumen yaitu pengumpulan data yang tidak langsung ditujukan kepada subjek penelitian, meneliti berbagai macam dokuken yang berguna sesuai bahan analisis sedangkan analisis data adalah proses merinci usaha secara formal untuk merumuskan data atau hipotesa.

\section{HASIL DAN PEMBAHASAN}

Berbicara mengenai pendidikan merupakan proses dari suatu pengembangan akan kemampuan seseorang, dan potensi serta keperibadian dari peserta yang dididik untuk melakukan dengan sadar akan usaha-usaha yang sudah ternecana ataupun matang yang bertujuan dapat bermanfaat bagi dirinya sendiri, maupun bagi masyarakat serta bagi bangsa dan juga negara, sedangkan makna yang tersirat dari pendidikan terhadap pancasila adalah atau merupakan bagian dari cara yang ada untuk memberikan dan menanamkan pribadi yang dianggap memiliki wawasan yang luas dan benar-benar bermoral di dalam kehidupan suatu bangsa dan bernegara. Sehingga dapat juga dijelaskan bahwa pendidkan tentang pencasila sangatlah perlu diberikan dari mulai tingkat yang paling mendasar lalu tingkat yang menegah dan sampai pada perguruan yang tinggi. Sebagaimana disebutkan Sari (2018) bahwa pelemahan dalam implementasi pemahaman pancasila terhadap mahasiswa disebabkan juga karena adanya pengaruh intern dan ekstern, 
dimana intern dalam diri mahasiswa yang bersangkutan dan ekstern berasal dari luar dirinya. Mahasiswa sebagai pilar bangsa harus mampu mengadaptasikan ilmu yang didapatkan selama dibangku perkuliahan yang sesuai dengan teori keadilan artinya tidak hanya memberikan keadilan pada diri sendiri tetapi keadilan di tengah tengah masyarakat, mengembangkan khazanah ilmu dan ikut terjun dalam masyarakat dengan mengembankan ilmu dan pengetahuannya agar dapat beguna bagim orang lain, selain itu jeremy bentham merumuskan teori kemanfaatan artinya memberikan manfaat kepada orang banyak dan hubungannya dengan perkembangan atau keseimbnagan antara kepentingan individu dan kepentingan masyarakat tidak hanya mementingkan kepentingan sendiri saja tetapi kepentingan masyarakat juga harus lebih diutamakan, dalam teori kepastian hukum mendasarkan bahwa setiap orang tidak dapat bertindak bebas sesuai keinginannya tetapi harus terikat pada aturan yang dibuat oleh penguasa agar warganegara tetap aman, tentram dan jauh dari segala ancaman.

Secara yang terdapat dalam etimologis makna atau kata Pancasila memang berasal atau terdapat dalam istilah Pancasila yang dapat diartikan sebagai suatu dasar yang memang memiliki 5 (lima) unsur. Supriyono (2014) menanjelaskan bahwa niali yang berbasis pancasila terhadap mahasiswa harus diikuti dengan rasa tanggung jawab, tepo selito dan memahami makna sila-sila dalam setiap butir pancasila, yang siftnya membangun dan menjaga rasa keharmonisan dalam masyarakat. Pancasila sendiri berasal dari India melalui bahasanya Sansekerta yang memberikan arti akan kata Pancasila yang memiliki 2 (dua) arti yang leksikal, yakni : Panca diartikan lima. Sila artinya sebagai batu sendi, atau alas, yang lebih dapat diartikan dasar ataupun peraturan yang mengatur akan tingkahdan laku dalam arti baik atau tidak baik.

Empat Dari landasan Akan Pendidkan Pancasila :

(i) Landasan yang Historis :

Setiap sila-sila yang terdapat dalam pancasila sebelum dilakuakn perumusan terlebih dahulu disahkan sebagai suatu dasar dari negara yang historis sehingga bisa dikatakan sebagai suatu kausa yang materialis dari Pancasila.

\section{(ii) Landasan yang Kultural :}

Adanya pandangan dari lehidupan dalam bermasyarakat dan berbangsa dan bernegara, dan melekatnya asas yang kultural sendiri. Adanya suatu nilai yang terkandng dalam sila pancasila merupakan suatu karya dari banga Indonesia sendiri yang memang merupakan suatu hasil dari karya yang dimiliki oleh dan melalui hasil dari proses para atau pendiri suatu negara secara refleksi dan filosofis.

\section{(iii) Landasan yang Yuridis:}

Landasan untuk pendidikan Pancasila khususnya dalam perkuliahannya untuk Perguruan Tinggi yang yuridis sesuai aturan dalam Undang-Undang Tahun 1989 Nomor 2 yang isinya tentang mengenai Sistem dari suatu Pendidikan Nasional, dimana pasal yang ke-39 pada hakikatnya menyatakan bahwa Isi dari kurikulum dalam setiap adanya jenis, maupun dari jalur dan atau jenjang dari pendidikan harus dan wajib mencantumkan dan memuat mengenai Pendidikan Pancasila, serta Pendidikan Agama, dan juga Pendidikan Kewarganegaraan.

\section{(iv) Landasan yang Filosofis:}

Realisasi akan keagamaan termasuk dalam bentuk proses dan reformasi karena bangsa Indonesia adalah bangsa yang berkemanusiaan dan berketuhanan yang sesuai dengan kenyataan yang disebut obyektif karena sebagai makhluk dari Tuhan Yang Maha Esa, dan dewasa ini 
tercermin dalam pelaksanaan pembangunan nasioanal dan aspek segala bidang kehidupan, yang meliputi pertahanan dan keamanan, ekonomi, dan sosial budaya juga politik serta hukum.

Kaelan (2013) Perguruan tinggi sebagai institusi pendidikan bagi mahasiswa, dalam berdedikasi, bertanggungjawab dan mempunyai nilai-nilai kepribadian yang luhur dan tidak hanya menghasilkan hasiswa dan mahasiswi yang dapat lulus dengan nilai yang baik tetapi harus berdasarkan juga dengan karakter yang sesuai dengan pancasila, artinya sesuai dengan implikasi sila-sila yang ada, mahasiswa harus dapat menerapkan dan mengaktualisasikan, implementasinya adalah sebagai berikut :

Sila I : Ketuhanan Yang Maha Esa, Setiap mahasiswa dapat beribadah sesuai dengan ajaran agamanya dan mata kuliah yang ada di setiap fakultas tidak menganggu jadwal beribadah, adanya sikap toleransi dan menghormati antara mahasiswa yang satu dengan yang lain sangat yang berbeda keyakinan,

Sila II : Kemanusiaan Yang Adil dan Beradab, mahasiswa berperan aktif dalam kegiatan kemanusiaan, membantu korban bencana alam, donor darah memberikan sumbagan berupa pakaian, makanan dan obat-obatan dalam hal ini tidak hanya menunjukkan rasa simpati tetapi empati dengan membuktikannya ada rasa perhatian terhadap sesama untuk saling meringankan penderitaan, melalui Badan Eksekutif Mahasiswa (BEM) melakukan koordinasi terhadap bantuan kemanusiaan,

Sila III : Persatuan Indonesia, menggalang antar berbagai organisasi mahasiswa untuk membentuk jaringan antar perkumpulan mahasiswa, sehingga satu sama lain saling mengenal, terbentuk jalinan yang harmonis dan adanya solidaritas diantara mahasiswa.,

Sila IV : Kerakyatan yang Dipimpin oleh Hikmat Kebijakanaan dalam Permusyawaratan/ Perwakilan Perwujudan akan sila ini dengan dilakukannya musyawarah untuk mufakat dalam pemilihan ketua BEM atau Ketua SENAT Mahasiswa beserta anggota-anggotanya, bukan hanya itu saja dalam pembentukan acara seminar nasioanal ataupun ataupun kegiatan yang lainnya senantiasa diadakan musyawarah untuk mendapatkan keputusan yang bersama berdasarkan suara yang bulat, mendiskusikan tidak terbatas antar sesama teman diantara mahasiswa dan juga mahasiswi tapi berdiskusi dengan dosen juga, dalam hal pengambilan kesepakatan bersama. Mardawani (2018) menjelaskan mahasiswa sebagai generasi muda harus dapat menceri jati diri yang sesungguhnya dengan melaksanakan musyawarah dalam mengmbil kepeutusan bertindak bersamsama tanpa harus memutuskan sendiri sebagai bentuk suatu rasa kekeluargaan.

Sila V : Keadilan Sosial Bagi Seluruh Rakyat Indonesia, Mematuhi aturan-aturan yang ada diperguruan tinggi, dan tidak boleh dilanggar, datang kuliah tepat waktu dan tidak terlambat, berpakaian yang rapi dan sopan, mengerjakan tugas dengan baik dan dikumpulkan, pada saat ujian tidak mencontek temannya tapi mengerjakan sendiri, jika aturan tersebut dilanggar akan adan sanksi yang diberikan, dan mahasiswa tersebut mau menerima sanksi yang berlaku, dan berjanji untuk tidak mengulanginya lagi artinya menyadari sepenuhnya bahwa ada tata terttib dan aturan yang ditegakkan.

Nilai-nilai kehidupan menurut Puji (2017) dalam pancasila yang sangat terbuka memiliki tiga dimensi, dengan dimensi yag idealistis dimana bersumber pada hakikat dan nilai-nilai yang dianggap dan dikatakan filosofis, dan juga mampu mendorong, menggugah dan memberikan motivasi kepada setiap pendukungnya untuk selalu dapat meraih apa yang akan dicita-citakan dalam masa depannya atau kehidupannya, dalam realisasinya mahasiswa mampu meraih akan cita-citanya selama berada di bangku perkuliahan, tidak 
saja pintar ataupun cerdas, tapi beriman, bertakwa, berbudi pekerti yang luhur serta mandiri dan bertanggungjawab terhadap dirinya sendiri ataupun kepada masyarakat, mampu mempertanggungjawabkan ilmu yang diperolehnya kelak setelah lulus dan kembali ditengah-tengah masyarakat.

Selanjutnya yang ke dua adalah dimensi yang normatif dimana pancasila dijabarkan dalam sistem norma yaitu sistem norma tertinggi, sebagaimana dalam aturan yang dapat mengikat dan mewajibkan untuk menjalankannya merupakan pandangan hidup suatu bangsa, dan norma terebut dianggap sudah melekat dalam diri mahasiswa, seperti norma hukun, kesusilaan, kesopanan dan agama.

Terakhir adalah Dimensi yang Realistis artinya dapat dan mampu menjabarkan secara nyata dalam kehidupan, tidak hanya secata teori saja dimengerti tetapi harus dilaksanakan dan dipraktekkan dalam kehidupan, menunjukkan bahwa dimensi yang ada dapat menumbuhkan keprtibadian yang sesuai dengan nilai nilai, norma dan moral dalam menjunjung tinggi akan ideologi pancasila yang bersifat terbuka di dalam kehidupan bangsa dan bernegara.

Perspekti perjuangan bangsa merupakan tujuan dan fungsi perguruan tinggi yang ada di seluruh Indonesia adalah Tri Dharma Perguruan Tinggi dan bukan juga hanya sekedar dari bagian tangging jawab mahasiswa saja, tetapi juga adlah tanggung jawab seluruh dosen atau pendidik, termasuk juga orang-orang atau siapapun yang terlibat didalamnya atau disebut juga dengan sivitas akademika memiliki tanggung jawab yang sama pula. Tri Dharma dari Perguruan Tinggi ini bertujua agar dapat mengaktualisasikan nila-nilai pancasila dalam masyarakat luas, mahasiswa dapat terjuan langusng ke tengahtengah masyarakat dan mengamalkan ilmu pengetahuan dan wawasannya selama berada di perguruan tinggi.

Menerapkan dan mempratekkan ilmu yang sudah didapatkan seperti disebutkan Putra, (2018), agar berguna bagi masyarakat, merupakan perwujudan dalam mengaktualisakan sila ke 2 yakni kemanusiaan yang adil dan beradab, mengembangkan pengetahuaannya agar dapat berguna bagi ns]usa dan bangsa adanya terpancar perwujudan sila ke-3 persatuan indonesia dan tanpa membedabedakan tiap orang, untuk memberikan dan mengajarkannya.

Bagian ataupun juga isi atau Bidang dari Tri Dharma Perguruan Tinggi adalah :

BidangPendidkan dan Pengajaran, Awal mulai mengikuti perkuliahan di semester 1 , tentunya sudah mendapatkan mata kuliah termasuk juga mata kuliah Pendidikan Pancasila, dan secara bertahap mendapatkan mata kuliah lainnya, seperti contohnya dalam bidang ilmu hukum, adanya hak asasi manusia, perlindungan anak dan perempuan, dan masih banyak lagi yang didapatkan, dengan mempelajari mata kuliah tersebut, mahasiswa tentunya dapat mengembangkannya sendiri ditengahtengah masyarakat, karena tidak semuanya masyarakat mengetahui dan memahami akan adanya hak tersebut, dan tidak mengetahui bahwa hak tersebut sudah ada sejak manusia dilahirkan dan kaena merupakan pemberian Tuhan Yang Maha Esa tentunya bagi yang melanggar hak tersebut akan diberikan sanksi yang sesuai dengan ketentuan hukum yang berlaku, dikarenakan juga masyarakat di daerah pedesaan tidak semuanya mengerti akan aturan hukum sehingga perlu adanya pengertian-pengrtian yang diberikan kepada kelompok masyarakat yang ada.

Bidang Penelitian, Bidang yang ke dua dari Tri harma suatu Perguruan Tinggi adalah Penelitian, sebagai seorang dosen merupakan keharusan dalam melakukan penelitian dan dari hasil penelitian dipublikasikan artikelnya ke dalam jurnal baik itu jurnal nasional yang terkareditasi atau juga dengan jurnal international untuk 
menaikkan jabatan fungsional.

Dalam melaksanakan penelitian dosen mengikutsertakan mahasiswa artinya ada keterlibatan mahasiswa disini, dengan keikutsertaan ini mahasiswa mengetahui tahap-tahap membuat proposal serta laporan penelitian, proposal dan laporan ini juga dibuat sesuai dengan pemahaman mahasiswa dalam mengembangkan teri dan konsep yang ada. Tidak diporbolehkan melakukan plagiat atau mencopy paste penelitian milik orang lain, jika mahasiswa sudah paham, akan dapat melakukan penelitian dan biasanya hasilnya juga dipublikasikan kedalam jurnal mahasiswa. implikasinya yang lain dikarenakan pada semester akhir akan melaksanakan skripsi atau tugas akhir, dalam melaksanakan seorang mahasiswa akan mengambil data, dengan data tersebut akan diolah dalam hal penyajian data.

Aco Agus dalam (2016), Misalnya saja, penelitian mengenai tindak perdagangan orang yang semakim marak, pelaku mendapatkan hukuman yang setimpal dan korban mendapatkan ganti rugi yang layak, dari hal ini bisa disimpulkan nilainilai kemanusiaan dalam sila pancasila sudah mulai luntur sedangkan Aqib (2011), tidak mengenal rasa belas kasihan, bukan barang lagi yang dijual tetapi sekarang adalah manusia, akibat perbuatan tersebut pelaku berhak mendapatkan sanksi yang berat atas kejahatan yang dilakukannya, dalam memutuskan pelaku bersalah atau tidak serta hukuman yang layak diberikan, tentunya hakim melakukan musyawarah untuk mendapatkan keputusan, hal ini sesuai dengan sila ke-4, kerakyatan yang dipimpin oleh hikmat kebijaksanaan dalam permusyawaratan.

\section{Bidang Pengabdian Kepada}

Masyarakat, tetap melibatkan mahasiswa disini mahasiswa menjelaskan tematema yang berkaitan dengan kegiatan abdi mas, kegiatan ini juga dalam rangka melakukan sosialisasi atau penyuluhan ke desa-desa. Mahasiswa berperan aktif dalam kegiatan kegiatan kerja mahasiswa (KKM), keterlibatan dosen disini bisa sebagai pembimbing KKM, kegiatan pengabdian masyarakat ini dilakukan dalam penyuluhan sekaligus juga menanamkan rasa persaudaraan dan saling mengenal satu sama lain, adanya persatuan dan kesatuan bangsa, terjalin kekompakan yang harmonis serta rasa solidaritas diantara masyarakat di tempat tersebut dengan mahasiswa.

Misalnya, Disamping memperkenalkan mengenai bidang dari hukum itu sendiri, tentunya adanya hak-hak untuk didampingi kuasa hukum, adanya pendampingan pembelaan melalui lembaga bantuan dan konsultasi hukum (LKBH), artinya masyarakat diarahkan untuk mendapatkan hak-haknya, mendapatkan pembelaan yang sesuai dengan hak-haknya. Para Mahasiswa yang turut serta dan berperan aktif sebagai narasumber dalam kegiatan ini, menyampaikan berbagai berbagai tema serta menjawab pertanyaan dari peserta. Keaktifan mahasiswa sekaligus memperkenalkan civitas akademik kepada masyarakat yang ada.

Dalam Endang Daruni (2003), Sehingga terjalinlah komunikasi yang baik diantaranya pihak-pihak yang terlibat dalam kegiatan pengabdian masyarakat ini. Dalam melakukan pengabdian tersebut biasanya ada kerjasama dengan tempat dimana melakukan kegiatan tersebut, tidak terbatas hanya dalam wilayah tertentu namun bisa saja ada suatu desa binaan, dimana masyarakatnya sudah diberikan penyuluhan, pelatihan secara rutin sehingga mereka sudah dapatmenerima, mengertidan memahami mengenai tema yang diberikan serta dapat mengimplementasikan di dalam kehidupanya, aktualisasi pancasila dalam hal ini terdapat dalam sila-sila dalam pancasila adanya keadilan sosial bagi seluruh rakyat Indonesia, adil dan saling menjaga persaudaraan 


\section{SIMPULAN}

Relevansi nilai-nilai dalam Pancasila sebagai Falsafah Negara Indonesia, tercermin di Perguruan Tinggi dalam Tri Dharma Perguruan Tinggi, yang sesuai dengan pendidikan karakter yaitu keimanan dan ketakwaan, bertanggung jawab, kejujuran, kedisiplinan, persatuan, saling menghormati dan toleransi. Wujud nyatanya mahasiswa ikut berperan aktif dalam kegiatan tri dharma perguruan tinggi dengan mengimplementasikan dalam kehidupan masyarakat dan mengembangkan ilmu pengetahuan yang sudah didapatkan di perguruan tinggi, (ii) Pengembangan Tri Dharma Perguruan Tinggi merupakan potret mahasiswa dalam berkontribusi secara nyata harus selalu dilaksanakan secara rutin, sehingga nantinya mahasiswa dapat menemukan jati diri sesungguhnya, dalam proses pembelajaran menuju dunia kerja yang baik

\section{DAFTAR PUSTAKA}

Aco, Agus A. 2016. Relevansi Pancasila Sebagai Ideologi Terbuka Di Era Reformasi. Jurnal Office, 2 (2), 229238 .

Aqib, Zainal. 2011. Panduan Dan Aplikasi Pendidikan Karakter. Bandung : Yrma Media

Endang, Daruni, Asdi. 2003, Manusia Seutuhnya Dalam Moral Pancasila, Yogyakarta : Pustaka Raja

Farida, Any. 2016. Teori Hukum Pancasila Sebagai Sintesa Konvergensi TeoriTeori Hukum Di Indonesia, Jurnal Perspektif : Kajian Masalah Hukum dan Pembangunan, 21 (1), 62-65.

Heryansyah, Despan. 2014. Tanggung Jawab Pemuda Terhadap Masa Depan Pancasila. Jurnal Hukum IUS QUIA IUSTUM, 21 (4), 607-631.

Ishal, Arfyand Anzhar Sapriya. 2018. Internalisasi Nilai-Nilai Pancasila Melalui Pusat Studi Pancasila Sebagai Upaya Penguatan Ideologi Bangsa Bagi Generasi Muda, Untirta
Civic Education Journal, 3 (2), 158167.

Kaelan. 2013. Negara Kebangsaan Pancasila: Kultural, Historis, Filosofis, Yuridis, Dan Aktualisasinya, Yogyakarta : Paradigma.

Kristioni, Natal. 2017. Penguatan Ideologi Pancasila Di Kalangan Mahasiswa Universitas Negeri Semarang. Jurnal Harmony, 2 (2), 193-204.

Mardawani, Lusiana. 2018. Peran Mahasiswa alam Upaya Membentuk Generasi Muda Berkarakter Melalui Pendekatan Humanis Berbasis Kearifan Lokal Suku Dayak Di Desa Telaga II. Jurnal Pekan, 3 (1), 1-9.

Misnaini, Sari. 2018. Pengaruh Pembelajran Nilai-Nilai Pancasila Terhadap Prilaku Mahasiswa Di STIK Bina Husada, Jurnal Ilmiah P2M STKIP Siliwangi, 5 (2), 75-84

Puji, Asmaroini Ambiro. 2017. Menjaga Eksistensi Pancasila Dan Penerapannya Bagi MasyarakatDi Era Globalisasi. JPK: JurnalPancasilaDan Kewarganegaraan, $1(2), 50-64$.

Putra, Zulfikar. 2018. Implemetasi Pendidikan Pancasila Sebagai Character Building Mahasiswa Di Universitas SembilanbelasNovember Kolaka. Jurnal Citizenship : Media Publikasi Pendidikan Pancasila dan Kewarganegaraan. 1 (1), 9-13.

Supriyono. 2014. Membangun Karakter

Mahasiswa Berbasis Nilai-Nilai Pancasila Sebagai Resolusi Konflik, Jurnal Educational Technology, 13 (3), 325-342

Syarbaini, Syahrial, 2011, Pendidikan

Pancasila (Implementasi Nilai-Nilai Karakter Bangsa) DI PERGURUAN TINGGI, Bogor : Ghalia Indonesia, Edisi Revisi, Cetakan keempat.

Yusuf, Muri, 2014, Metode Penelitian, Kuantitatif, Kualitatif, \& Penelitian Gabungan, Jakarta : Prenadamedia Group 